\title{
THE STAKEHOLDERS' INFLUENCE ON THE OPERATIONAL SYSTEM OF ORGANIZATIONS: CASE OF PUBLIC ADMINISTRATIONS IN TUNISIA
}

\section{Dr. Mohamed Karim AZIB}

Assistant Professor, Faculty of Economics and Management Sciences of Tunis, Tunis El Manar University, Tunisia.

Research Laboratory, Applied Research in Business Relationships and Economics (ARBRE), University of Tunis, Tunisia

\begin{abstract}
The objective of this research work was to analyze and evaluate the influence of stakeholders on the operational system of organizations. The conceptual analysis allowed to study the interests and the manifestation of the stakeholders' influence on the activity and the functioning of the organizations. The analysis showed that stakeholders aspire to the information access, to share the material wealth created and to benefit from the organization's commitment. The theoretical study highlighted the components of an organization's operational system: the use of resources, the leadership practiced and the established organizational model. The empirical analysis realized with a sample of public establishments validated all the items of the research proposal and showed that the stakeholders' influence is mainly exerted on the use of resources. The influence of stakeholders on the organizational model and the leadership practiced are positioned, respectively, in second and third positions.
\end{abstract}

Key words: Stakeholders' Influence, Operational System, Resources Use, Leadership Practiced, Organizational Model, Public Organizations.

Cite this Article: Mohamed Karim AZIB, The Stakeholders' Influence on the Operational System of Organizations: Case of Public Administrations in Tunisia, International Journal of Management, 11(12), 2020, pp. 2390-2398.

http://iaeme.com/Home/issue/IJM?Volume=11\&Issue=12

\section{INTRODUCTION}

The organizations' openness to their environment, the imperative of integrating into the institutional framework and the orientation of the concretization of a partnership and participative governance based on social responsibility leads to a reinforcement of the stakeholders' interest and the increasing of their power of influence on the management and 
the functioning of public and private organizations. The operational system (or the functioning of the organization) is a determining component of managerial activity because it relates to processes, centers of responsibilities, capacities and potentials to be valorized with the modes of animation and coordination of the various functions. An operational system and an efficient functioning promote the creation of value for an organization and its partners. This paper intends to study this question: what is the importance of stakeholders' influence on the operational system of the organizations? This work will include an analysis of stakeholders' interests that justify their involvement and influence on the operational system and the functioning of organizations. The conceptual study will be devoted to the analysis of the foundations and the elements of the operational system. The synthesis of the theoretical analysis will enable the presentation of a research proposal based on the impact of stakeholders' influence on the operational system and its components. This research proposal will be tested and validated through an empirical survey to be carried out among a sample of public administrations. This empirical analysis will allow to assess the importance of the stakeholders' influence on the operational system and its components.

\section{THE STAKEHOLDERS' INTERESTS AND THE MANIFESTATIONS OF THEIR INFLUENCE}

The purpose of the management practice is to create value for the organization and for its stakeholders [1]. The leaders must integrate stakeholders' interests, assess the economic and the social impacts of the decisions to be made, the actions to be taken and the configuration of the organization's operational system on the situation of the partners $[2,3,4,59]$. The operating system can no longer be limited to the contractual, legal and economic aspects with the shareholder as a privileged partner; it must evolve towards a more global approach of the governance and the efficient functioning of organizations by integrating all stakeholders in a differential way $[4,5,59]$. The power of influence and the impact of stakeholders on the functioning of the organization is variable; they are distinguished by the legitimacy and the urgency of their needs [6]. An organization's operational system may create risks for stakeholders; the consequences of these risks need to be regularly assessed [7]. The stakeholders seek to increase their negotiating power, influence the functioning of organizations, express expectations, look for solutions to concretize their objectives and have the means to act and exert pressures [4, 8, 9]. The shareholders are looking for a return on investment and the protection of the organization's tangible and intangible assets; they demand sincerity of information and accountability of managers for the performance achieved. The shareholders are involved in the operations of the organization, through their ownership of the capital, which allows them to exercise control on the management and to intervene in decision-making. The managers have to arbitrate between the shares of the profits to be distributed to the shareholders and to be invested in the development of the organization's activity $[4,9]$. The shareholders have several means of action at their disposal, such as the requirement of transparency and access to information, the transactions (transfers or acquisitions) they make with their shares and the possibility of initiating legal procedures [8].

The customers (consumers or distributors) demand that commitments be respected. The operational system should include processes that promote quality management, cost control and the reduction of delays, enabling the client to benefit from a competitive offer. The suppliers wish to perpetuate their business relationships as providers of resources for the functioning of the organization; they aim to position themselves as partners and integrate themselves into the strategic choices of the organization through the competitiveness of their offer. The suppliers expect the organization to be solvent and to respect its contractual 
agreements [4, 9]. The customers (consumers or distributors) and suppliers influence the organization's operational system through their negotiation of the financial terms of transactions, through their control of distribution and supply channels and through their technical contribution to the value chain [8]. The organization's human resources (executives, managers or operational staff) aspire to motivating remuneration, recognition of their contribution, rewarding working conditions and attractive career prospects that promote the development of their skills $[4,9]$. The human resources influence the operational system of the organization through their level of technical and managerial skills, their efficiency in the use of resources, their support for the decisions taken, their initiative or passivity, the work climate they create, their degree of solidarity and collaboration, the level of information sharing, by their recommendations, criticisms and requests. The human resources constitute formal and informal relational networks that can be sources of alliances, partnerships and conflicts inside the organization [8].

The unions aim to take root in the governance of an organization by positioning themselves as representatives of human resources and defenders of their interests $[4,9]$. The unions influence the operational system of an institution through their ability to mobilize staff to support or disapprove the managerial action of the executive management; the influence of unions is manifested through their actions and negotiations to provide financial and nonfinancial benefits to the organization's staff [8]. The governments (or public authorities) aim to implement economic, social and environmental policies and programs; they have the power to regulate the business environment and encourage organizations to contribute to wealth creation and social stability [4,9]. The public authorities have an impact on the operational system of the organizations by the imperative of conformity to laws, to administrative and fiscal directives that have an impact on the financial resources of organizations. The political and the administrative leaders exert pressures through their relational networks, by influencing public opinion, by media communication and by dialogue between the business environment and public institutions [1,8]. The funders aim to realize profitable financial operations; they seek to secure transactions and control risks by requiring guarantees of solvency and by guiding the choice of projects and investments. The funders are interested in long-term partnerships with organizations that they consider credible [4, 9]; they influence the operational system of organizations through their ability to provide access to financial resources (risk assessment, financing cost and funding modalities), their advice and recommendations and their control and supervision of the projects they are financing [8].

The stakeholders intend to benefit from the value created by the organization. The power of stakeholders' influence varies according to their impact and their involvement in the managerial activity and the functioning of the organization concerned. The nature of the stakeholders' influence can be formal or informal, permanent or temporary, global or targeted, direct or indirect and by adhesion or resistance. The stakeholders have an impact on the operational system by different types of relationships and behaviors that are manifested by the exercise of authority or power, possibilities of collaboration, compromises found by negotiation and situations of disagreement and conflict $[1,8,10]$. Several factors contribute to the influence of stakeholders on the operational system of an organization [10]:

- The ownership, control and mastery of the use of tangible and intangible resources essential for the functioning of organizations.

- The holding of a decision-making power (or delivery of authorizations) and involvement in the policy-making process within the framework of a partnership governance.

- The extended access to information through the development of platforms and the involvement of stakeholders in the organizational learning process. 
The Stakeholders' Influence on the Operational System of Organizations: Case of Public

Administrations in Tunisia

- The monitoring and the evaluation of the consequences of decisions and actions taken by the executive management team.

- The ability to mobilize resources to exert pressures, mediatize claims, conduct negotiations, engage in conflict situations and take legal action.

- The imposition or the proposal of standards, conventions and rules to regulate the organizations' activities.

The stakeholders influence the operating practices of the organizations to generate benefits and advantages of various kinds: financial income, access to information to limit risks and a guarantee of the organization's commitment regarding the consequences of the decisions taken $[1,11,12,13]$. The stakeholders demand transparency in decision-making processes, the establishment of partnerships and reciprocities that are mutually beneficial to them and to the organization based on managerial practices and a mode of operating that are characterized by regularity; these means of action aim to build trust between the partners and the organization $[11,12,13]$.

\section{THE APPROACHES AND THE COMPONENTS OF THE ORGANIZATIONS' OPERATIONAL SYSTEM}

\subsection{The Diversity of Approaches of Organizations' Operational System}

The analysis of the functioning of organizations shows a diversity of approaches that reveal the operational characteristics of managerial action. The functioning mode of an organization can be analyzed as an operational system based on the coordination of several variable components $[14,15,16,17]$. These variables are linked, such as the history of the activity, the organizational model adopted (size and centers of responsibilities), the leadership practiced, the ethics consecrated, the strategic choices, the human resources that can be mobilized, the technology used, the competencies and skills available [18, 19, 20, 21, 22, 23, 24]; these factors show the contingency of any organization's operational system that is based on the exercise of power determined by the possession of information and the interdependencies between individuals and departments [25]. Consequently, the operational system is the result of a balance to be found between collective and individual objectives [26]; this implies the existence of a network of contractual relations [27] and the establishment of an organizational model that enables the control of transaction costs $[28,29,30]$. The functioning is also bureaucratic, procedural, standardized and institutional, with a legal and technical logic based on compliance with internal and external rules [31, 32]. The operational system should be integrated into an ecosystem by being adapted to the contingencies of the business environment $[33,34]$ and oriented towards the satisfaction of stakeholders to attract and capitalize the resources necessary for the viability of the organization's activity [35, 36, 37]. The ownership and the sharing of resources (including skills) can generate synergies [38]. The functioning of an organization implies the existence of a manager called to propose solutions to problematic situations and to decide on the basis of a limited rationality [39, 40] determined by their level of knowledge and their personal appreciations. In order to concretize the decisions taken, the manager has to finalize, organize and lead his team [40, 41].

\subsection{The Components of the Operational System}

The operational system is based on the use of resources, the style of leadership practiced and the establishment of an organizational division $[11,12,13]$. The operational system involves the efficient use of tangible and intangible resources; the resources reveal the capacities and potential of the organization; they can be a source of weaknesses or competitive advantages. 
A planned and relevant functioning requires coherence between the objectives and the resources with priorities setting [42,62]. The leadership requires authority and a mode of exercising power to mobilize resources, animate work teams, guide managerial behavior and canalize efforts towards the organization's objective; the choice of leadership style depends on the preferences of the leader, the profile of the collaborator and the characteristics of the organizational context $[43,44,45,60,61,62]$. The operational system determines the division of activity by the distribution of roles, tasks and functions (decision, execution, evaluation and expertise), the delimitation of responsibility centers, the work procedures, the hierarchical (vertical) and collaborative (transversal) relationships, the decision-making processes and the information circuits $[10,46,47,62]$. The configuration of the operational system is the vector for implementing the solutions decided by managers, serves as an action guide for operational staff in order to accomplish their activities and enables them to test the significance of risks, the contribution of strengths and the extent of weaknesses in the organization's operations [11, $12,13]$.

\section{THE RESEARCH PROPOSAL AND THE FORMULATION OF THE HYPOTHESES}

The theoretical study allows the presentation of a research proposal based on the impact of the stakeholders' influence on the operational system and the functioning of the organization. The stakeholders seek to benefit from the wealth created, the information and the commitment of the organization $[1,11,12,13]$. The main hypothesis considers that stakeholders' influence exerts an impact on the operational system and the functioning of the organization (H1). The other three hypotheses are related to the stakeholders' influence on the resources use (H2), on the leadership practiced (H3) and on the organizational model (H4).

\section{THE EMPIRICAL METHODOLOGY}

The approach adopted is based on a positive and hypothetico-deductive methodology. The empirical approach was based on a convenience sample of 67 public administrations which are operating to concretize a mission of general interest and public service; a questionnaire was submitted to public managers by direct interviews $[48,49,50]$. Their opinions and appreciations about the impact of stakeholders' influence on the operational system of public organizations were collected by using the Likert scale.

\section{THE EMPIRICAL RESULTS}

\subsection{The Empirical Validation of the Research Proposal}

The empirical study of the impact of stakeholders' influence on the operational system and its components requires, first, an analysis of the reliability of the measurement scale to validate the internal coherence between the items and a factorial analysis to confirm the unidimensionality of the proposed items (Table 1).

Table 1 The validation of the research proposal's items

\begin{tabular}{lcccc}
\hline \multicolumn{1}{c}{$\begin{array}{c}\text { Name of the extracted } \\
\text { component }\end{array}$} & $\begin{array}{c}\text { Cronbach's } \\
\text { Alpha }\end{array}$ & KMO & $\begin{array}{c}\text { Bartlett's } \\
\text { test of } \\
\text { sphericity }\end{array}$ & $\begin{array}{c}\text { Total } \\
\text { variance } \\
\text { explained }\end{array}$ \\
\hline Stakeholders Influence (SHI) & 0,798 & 0,603 & 0,000 & 71,655 \\
\hline Resources Use (RU) & 0,728 & 0,652 & 0,000 & 66,271 \\
\hline Leadership Practiced (LP) & 0,779 & 0,666 & 0,000 & 69,806 \\
\hline Organizational Model (OM) & 0,862 & 0,581 & 0,000 & 78,473 \\
\hline Operational System (OS) & 0,936 & 0,724 & 0,000 & 88,641 \\
\hline
\end{tabular}


The results concerning the Cronbach's Alpha validate the reliability of the measurement scale and the internal coherence between the items proposed to evaluate the impact of the stakeholders' influence on the operational system and its components (resources use, leadership practiced and organizational model).

The principal component analysis with the Varimax method validates the proposed variables, through, the results of the KMO index (measure of sampling adequacy), the Bartlett's test of sphericity always significant $(\operatorname{sig}=0.000)$ and the total variance explained (extraction sums of squared loadings) and the extraction in all cases of a single dimension.

\subsection{The Evaluation of the Impact of the Stakeholders' Influence on the Operational System}

The evaluation of the impact of the stakeholders' influence on the operational system of public organizations was realized by analyzing the results of linear regressions to validate this impact and determine its relative importance on each component of the functioning of public organizations (Table 2).

Table 2 The evaluation of the impact of stakeholder's influence on the operational system and its components (summary of significant models; Sig. $=0,000$ )

\begin{tabular}{lc}
\hline \multicolumn{1}{c}{ Standardized coefficients } & Adjusted R Square \\
\hline $\mathbf{O S}=0,651$ SHI $-4,255 \mathrm{E}-17$ & 0,414 \\
\hline $\mathbf{R U}=0,701 \mathbf{S H I}-2,316 \mathrm{E}-17$ & 0,483 \\
\hline $\mathbf{L P}=0,493 \mathbf{S H I}-1,184 \mathrm{E}-16$ & 0,231 \\
\hline $\mathbf{O M}=0,639$ SHI $-6,490 \mathrm{E}-17$ & 0,399 \\
\hline
\end{tabular}

The results obtained (Table 2) confirm the decisive impact of the stakeholders' influence ("t of student" $=6.906$; $\mathrm{sig}=0.000$ ) on the operational system of public organizations (validation of hypothesis H1).

The stakeholders exert their most important influence on the use of resources in public organizations $(\mathrm{t}=7.921$; sig $=0.000)$; their impacts on the organizational model $(\mathrm{t}=6.701$; $\operatorname{sig}=0.000)$ and the leadership practiced $(\mathrm{t}=4.564$; $\mathrm{sig}=0.000)$ are in second and third positions, respectively (validation of hypotheses $\mathrm{H} 2, \mathrm{H} 3$ and $\mathrm{H} 4$ ).

\section{THE INTERPRETATION AND THE DISCUSSION OF THE RESULTS}

The empirical results obtained demonstrate the importance given by the partners of public organizations to the use of community resources; this explains the importance of hierarchical authorizations, controls and audits to ensure legality and efficiency in the use of public resources [52]. The control of the resources use is no longer the monopoly of administrative regulatory departments; this monitoring is carried out by a diversity of stakeholders, such as: the citizen-user, the civil society, the political parties, the media and the alert launchers, which shows the evolution towards a partnership and participatory public governance that integrates the stakeholders in the design, execution and evaluation of public services [53, 54]. The priority given by stakeholders to transparency in the use of resources explains the requirements of legality, integrity and impartiality imposed to public leaders to avoid conflict of interest situations that can lead to abuse and corruption [58]. The increasingly limited budgets are leading public organizations to consider partnerships with private operators [53, 54]. The stakeholders' influence favors an organizational model oriented towards decentralization of decision-making for a better valorization of competencies and a greater responsibility of public managers regarding the results achieved; the management of 
stakeholders' relationships requires an organizational model focused on customer satisfaction, added value of processes, problem solving, flexibility, initiative and performance instead of an organizational model focused on hierarchy, compliance with procedures, standardization of managerial behavior and expenditure of budget allocations [53, 54, 55, 56, 57]. The influence of stakeholders on the leadership practiced is manifested by the demand for exemplarity in the managerial behavior of public leaders: political decision-makers and administrative managers; these two dimensions of leadership in public organizations may follow divergent approaches $[53,54,55,56,57]$. The public management requires a mobilizing and transformational leadership oriented towards projects and reforms based on a vision, a mission, objectives and values [51].

\section{CONCLUSION}

The objective of this research work was to analyze and evaluate the impact of stakeholders' influence on the operational system of organizations. The conceptual analysis was consecrated to the analysis of the interests of the main stakeholders and the manifestation of their influence on the management of an organization; the stakeholders aspire to benefit from the access to information, the sharing of the wealth created and the commitment of the organization. The theoretical study outlined the components of an organization's operational system: the use of resources, the leadership practiced and the organizational model. The empirical analysis conducted with public institutions validated all the items of the research proposal and demonstrated that the stakeholders' influence is mainly exerted on the use of resources. The stakeholders' influence on the organizational model and the leadership practiced are in second and third place, respectively. This result reflects the stakeholders' interest about the way how public organizations and their leaders allocate and spend the community's resources when implementing public policies, strategies and programs. The stakeholders play a key role in the governance of public organizations through their monitoring of the efficient and transparent use of resources and their pressure to ensure that the allocation of resources supports the realization of their interests. The stakeholders' influence favors the orientation towards decentralized organizational models that allow public leaders to have greater decision-making autonomy and flexibility to respond in a differentiated way to partners' expectations. The decentralization implies the implementation of a goal-oriented public management. The stakeholders' influence on the leadership practiced is manifested by the demands for exemplary public leaders who must demonstrate impartiality, legality, transparency and integrity in the exercise of their functions; these public leaders have to propose to the stakeholders a clear vision and practice transformational leadership to reform public administration for better performance and quality of the action deployed. This research work can be deepened by analyzing the contribution and the influence of stakeholders in the management of changes in public organizations.

\section{REFERENCES}

[1] Magakian, J.-L. 100 fiches pour comprendre la stratégie d'entreprise. Paris: Bréal, 2002.

[2] Jonas, H. Le principe responsabilité. Paris: Editions du Cerf, 1990.

[3] Amadieu, J. F. Responsabilité sociale de l'entreprise. In: Le Duff R., ed., Encyclopédie de la gestion et du management. Paris: Dalloz, 1999, pp. 1082-1083.

[4] Mercier, S. L'éthique dans les entreprises. Paris: La Découverte/Syros, 1999.

[5] Goodpaster, K. E. Business ethics and stakeholder analysis. Business Ethics Quaterly, 1, January 1991, pp. 53-73.

[6] Mitchell, R. K., Agle, B. R. and Wood, D. J. Toward a theory of stakeholder. Identification and salience: defining, the principle of who and what really counts. Academy of Management Review, 22(4), 1997, pp. 853-886. 
The Stakeholders' Influence on the Operational System of Organizations: Case of Public

Administrations in Tunisia

[7] La Bruslerie, H. Le rôle de l'éthique du respect dans la déontologie économique et la gestion. Direction et Gestion des Entreprises, 164-165, 1998, pp. 73-86.

[8] Capet, M., Causse, G. and Meunier, J. Diagnostic, organisation, planification d'entreprise: diagnostic et politique générale. Volume 1, Paris: Economica, 1986.

[9] Darbelet, M., Izard, L. and Scaramuzza, M. Notions fondamentales de management. Vanves: Foucher, 2004.

[10] Mintzberg, H. Le pouvoir dans les organisations. Paris: Editions d'Organisation/Editions Agence d'ARC, 1986.

[11] Azib, M. K. La coordination entre le cadre institutionnel et le système de gestion dans le management de l'entreprise : analyse comparative entre le secteur privé et le secteur public en Tunisie. Ph. D. Dissertation, Tunis: Faculty of Economics and Management of Tunis, 2012.

[12] Azib, M. K. and Frioui, M. The coordination between the institutional framework and the management system of the firm: comparative analysis between the public sector and the private sector in Tunisia. International Journal of Business and Management Studies, 4(2), 2012, pp. 117-128.

[13] Azib, M. K. The interaction between the components of the management system of the firm: a comparative analysis between public and private enterprises in Tunisia. International Journal of Business and Management Studies, 5(2), 2013, pp. 201-2013.

[14] Von Bertallanfy, L. Théorie générale des systems. Paris: Dunod, 1973.

[15] Mélèse, J. La gestion par les systems. Paris: Hommes et Techniques, 1968.

[16] Mélèse, J. L'analyse modulaire des systèmes de gestion. Paris: Hommes et Techniques, 1972.

[17] Emery, F.E. and Trist, E.L. Socio-technical systems, In: Churehman C. and Verhulst M., ed., « Management science, models and techniques », 2, Oxford: Pergamon Press, 1960, pp. 83-97.

[18] Stinchombe, A. Social structure and organizations » In: March, J. G., ed., Handbook of organizations, Chicago: Rand-McNally, 1965, pp. 142-193.

[19] Woodward, J. Industrial organisation: theory and practice. London: Oxford University Press, 1965.

[20] Blau, P. The formal theory of differenciation in organization. American Sociology Review, 35, 1970, pp. 201-218.

[21] Chandler, A. D. The visible hand: the managerial revolution in american business. Cambridge: Harvard University Press, 1977

[22] Peters, T. and Waterman Jr R. H. Le prix de l'excellence. Paris: InterEditions, 1983.

[23] Perrow, C. B. Complex organizations: a critical essay. Glenview: Scott, Foresman, 1972

[24] Perrow, C. B. Normal accidents: living with high-risk technologies. New York: Basic Books, 1984.

[25] Crozier, M. and Friedberg, E. L'acteur et le système. Paris: Seuil, 1977.

[26] Cyert, R. M. and March, J. G. A behavioral theory of the firm. New Jersey: Englewood Cliffs, Prentice-Hall, 1963.

[27] Fama, E. F. and Jensen, M. C. Separation of ownership and control. Journal of Law \& Economics, University of Chicago Press, 26(2), June 1983, pp. 301-325.

[28] Coase, R. H. The nature of the firm. Economica, New Series, 4(16), 1937, pp. 386-405.

[29] Williamson, O.E. Markets and hierarchies: analysis and Antitrust Implications. New York: Free Press, 1975.

[30] Williamson, O. E. The economic institutions of capitalism. New York: The Free Press, 1985.

[31] Di Maggio, P. J. and Powell, W. W. The new institutionalism in organizational analysis. Chicago: University of Chicago Press, 1991.

[32] Brunsson, N. The organization hypocrisy. Talk, decisions and actions in organizations. Wiley: Abingdon and Oxfordshire, 2002.

[33] Burns, T. and Stalker G. M. The management of innovation. London: Tovistock, 1961.

[34] Lawrence, P. R. and Lorsh, J. W. Adapter les structures de l'entreprise. Paris: Editions d'Organisation, 1973.

[35] Pfeffer, J. and Salancik, G. The external control of organizations: a resource dependence perspective. New York: Harper \& Row, 1978 
[36] Aldrich, H. Organizations and environment. New Jersey: Englewood Cliffs, Prentice Hall, 1979.

[37] Hannan, M. and Freeman, J. The population ecology of organizations. American Journal of Sociology, 82(5), 1977, pp. 929-964

[38] Nelson, R. R. and Winter, S. G. An evolutionary Theory of economic Change. Cambridge: Harvard University Press, 1982.

[39] Simon, H. Administrative behavior. New York: The Free Press, 1947.

[40] Mintzberg, H. Le manager au quotidien: les dix rôles du cadre. Paris: Editions d'Organisation, 1984.

[41] Drucker, P. F. La nouvelle pratique de la direction des entreprises. Paris: Editions d'Organisation, 1977.

[42] Louart, P. Ressources. In: Le Duff, R., ed., Encyclopédie de la gestion et du management. Paris: Dalloz, 1999, pp. 1083-1084.

[43] Robbins, S. and DeCenzo, D. Management: l'essentiel des concepts et des pratiques. Paris: Pearson Education, 2004.

[44] Helfer, J.-P., Kalika, M. and Orsoni, J. Management, Stratégie et organization. Paris: Vuibert, 2008

[45] Meier, O. Dico du manager, 500 clés pour comprendre et agir. Paris: Dunod, 2009.

[46] Tabatoni, P. and Jarniou, P. Les systèmes de gestion: politiques et structures. Paris, Presses Universitaires de France, 1975.

[47] Livian, Y. F. Organisation: théories et pratiques. Paris: Dunod, 1998.

[48] Evrard, Y., Pras, B. and Roux, E. (in collaboration with. Choffray, J.-M., Dussaix A.-M., Claessens M.) Market, études et recherches en Marketing. Paris: Dunod, 2000.

[49] Stafford, J. and Bodson P. L'analyse multivariée avec SPSS. Québec: Presses de l'Université du Québec, 2006.

[50] Carricano, M. and Poujol F., Analyse de données avec SPSS, Paris: Pearson Education, 2009.

[51] Tremblay, M., Chênevert, D., Simard, G., Lapalme, M.-E. and Doucet, O. Agir sur les leviers organisationnels pour mobiliser le personnel: le rôle de la vision, du leadership, des pratiques de GRH et de l'organisation du travail, Gestion, 30(2), 2005, pp. 69-78.

[52] Gortner, H. F., Mahler, J. et Nicholson, J. B. La gestion des organisations publiques. Québec: Presses Universitaires du Québec, 1994.

[53] Chevalier, G. (Preface by Igalens J.) Eléments de management public, le management public par la qualité. Paris: Afnor Editions, 2009.

[54] Bartoli, A. Management dans les organisations publiques. Paris: Dunod, 2009.

[55] Cohen, A.-G. La nouvelle gestion publique. Paris: Gualino, 2012.

[56] Proulx, D. Management des organisations publiques: Théorie et applications. Québec: Presses de l'Université du Québec, 2010.

[57] Thom, N. and Ritz, A. Le management public: Concepts innovants dans le secteur public. Lausanne: Presses Polytechniques et Universitaires Romandes, 2013.

[58] OECD, Renforcer l'intégrité en Tunisie: l'élaboration de normes pour les agents publics et le renforcement du système de déclaration de patrimoine. OECD, 2014.

[59] Deslandes, G. Le management éthique. Paris: Dunod, 2012.

[60] Duséhu, B. Le manager de proximité: Le management opérationnel au coeur de la performance de l'entreprise. Le Mans: Gereso, 2019.

[61] Ramond, Ph. Le management opérationnel des équipes: Direction et animation. Paris: Maxima, 2017.

[62] Baranger, P., Godefroy Dang Nguyen, G., Leray, Y. and Mével, O. (Preface by Gallouj, C.) Management Operationnel des Services, Paris: Economica, 2016. 